Prof. H.F. van Rooy

Department of Semitic Languages

\title{
BENJAMIN FRIEDMAN ON ARABS IN ISRAELI LITERATURE
}

Benjamin Fricdman was working on a thesis for his doctorate at the University of Potchefstroom when he passed away in 1979. He was immenscly interested in the way the Israeli Hebrew writers pictured the Arabs in their fiction and had done a massive amount of research when he died. He was therefore unable to complete his research and to present his views in a complete study. He did, however, leave a manuscript which reflected his research and conclusions. This was edited by his family ${ }^{1}$ and the University of Potchefstrom gave recognition to his work by awarding him the degree M.A. posthumously. The writer of this paper added a chapter to Mr. Friedman's manuscript, summarising his main views on the topic. Menahem D. Rotshtein's paper on this same subject ${ }^{2}$ prompted me to present Benjamin Friedman's view on this important subject, in aid of further research and discussion.

He discerned two distinct periods in the approach to the Arabs and the Arab problem in Israeli Hebrew literature. The lirst period comprises the years before the Second World War, the first four decades of this century. The second period is the years since the War of Liberation of 1948. The period from the beginning of the Second World War up to the end of the War of Liberation must be viewed as a time of fluctuation and transition. The literature in the different periods does not present a uniform approach to the Arabs, but there are certain preponderant trends in the different periods. The aim of his study was to define the different trends in the different periods, with emphasis on the sccond period. The trends are summarised in this paper to show the development in the approach to the Arabs in the different periods, according to Benjamin Friedman. This summary is followed by a discussion of the different trends in the different periods.

In the first period, the first four decades of this century, the main approach to the Arabs was romantic, simplistic and even idealistic.

' Arabs as portrayed in the Isracli Hebrew litcrature since the Second World War. Potchefstroom 1981.

2 "Study in Ambivalence: Arabs in Isracli Firtion". JUDAISM (Fall 1981): 484-494. 
$\Lambda$ few writers had an eye for the problemat ic side of the relation between the Jews and the $\Lambda$ rabs, but they remained in the minority.

During the years of the Sccond World War and immediately afterwards, different trends can be discerned. Some of the writers, chiefly the older writers, tried to keep the romanticism of the first period alive, despite the harsh realities of their time. Others, especially the native-born writers, present an ambivalent approach. There is something of the romantic approach in their litcrature on the one hand and even envy of the Arabs that are so completely at home in the coveted land. On the other hand these writers were confronted with the reality of the approaching war against the Arabs and they felt revulsion at the primitive lifestyle and the filth of the Arabs in their settlements.

In the second period, since the Jewish War of Liberation of 1948, three main trends can be defined. The first one is encountered in the literature aimed at the youth throughout this period. It is a naive approach to the problem, expressing a yearning for the good old days of friendship that are no more. The second trend can be seen in the literature of the time immediately following the War of Liberation, and also in literature following the subsequent wars between Israel and the Arab states. The Arab problem is a daily reality for these writers. The political problems, the alienation between.Jews and Arabs and the expulsion of the Palestinian Arabs resulted in remorse and feelings of guilt in the minds of these Israeli Hebrew writers. The social disintegration of the Arabs is noted and linked to the polit ical and military problems.

The third trend in the period since the War of Liberation appears at the beginning of the Sixties, when a new generation of writers, the so-called Canaanites, came to the fore. The writers of the first period wrote against the backdrop of the Diaspora and the writers of the years following the Second World War paid special attention to both the Diaspora and the Holocaust. These writers of the new generation saw their work as a continuation of Biblical times, ignoring the Diaspora. They regarded the confrontation between Arab and Jew as a part of a life and death struggle, such as faced the Israelites at the time of their entrance into the promised land. The Israelites had to face the Philistines, the Moabites and all the other hostile nations of Canaan in their struggle for survival and the new Israelites have to face the Arabs. For these writers terrorism is part and parcel of their dialy life, Icading to lurther alienation between Arab and Jew. To them the Arabs are a menace that one has to overcome by force.

The writers of the first period hailed mainly from Eastern Europe. The 
strange surroundings of Israel made deep impressions on them, creating the feeling that they were carried back to the ancient Eretz Israel of the Bible. The romantic idea tha the Arabs were the Jewish peasants that were forced to abandon their faith appears with some frequency in their work. The main exponent of this romantic approach was $\mathbf{M}$. Smilansky. He was indeed a friend of the Arabs. In his sentimental approach to the Arabs he was charmed by their romanticism and simplicity.

This romantic approach can clearly be discerned in the many stories of the sentries. The sentries became well acquainted with the Arabs and even copied their way of life and language. They wanted to be shepherds and tillers of the soil - and the Arabs gave them an example to copy. Friendship between Arab and Jew is a common theme. The literature of this period reveals an intimate knowledge of the Arab way of life, of Arab thought, aspirations, values and virtues. The tragic side of the Arabic existence is the object of many sympathetic portrayals by writers such as Smilansky and Churgin. These writers, and especially Smilansky, were inspired by a strong desire for a peaceful and friendly co-existence with the Arabs. This ideal is the starting-point of many stories from this period.

The negative side of the relationship between Jews and Arabs was touched on by a smaller group of writers from this period, with Steinberg and Brenner as the more important figures. They had an eye for the human situation of strangers, rivals, claiming the same motherland. Tension and mistrust must be seen beneath the surfacc. Amongs these writers were quite a few native-born writers who had the desire to understand the Arabs, but who remained suspicious of them. The problem came more to the fore with the awakening of Arab national consciousness, which led to the riots of 1929 and 1939. This slowly eroded the Jewish romantic illusions aloout the Arabs. The main stumbling-stones were ownership of the land, competition between Arab and Jewish labourers and the alicnation of the Jewish farmers from their Jewish worker brethren. These problems resulted in a more realist ic and critical approach to the whole matter. The Arabs were seen as part of the host ile landscape, as a physical factor threatening the existence of the Jewish minority in the Land of Israel. As a result of this Brenner was quite critical of the romantic and optimistic approach of Smilansky and others like him. Brenner saw the chasm that existed between Jews and Arabs, even describing the Arabs as a volcano about to crupt.

In the transition period from the beginning of the Second World War till the end of the War of Liberation the romantic approach continued, especially in the works of the older writers that were unable to adapt to the new menacing circumstances. Some writers, like Sharoni and Ravina, still strove for a 
better understanding of the Arabs linked with an identification with the primitive Arab way of life, as something reminding them of the biblical past.

A new development can, however, be discerned in the writings of the younger writers of that time. An ambivalent approach appears in their work. Something of the romantic approach of the first period lingered on in their work. 'They also expressed the desire to live in peace with the Arabs. There are even traces of envy on their part of the Arab's attachment to the ways of the land. On the other hand they were faced with the reality of the military preparations for the coming war against the Arabs. They also felt revulsion at the filth of the Arab settlements, and their primitiveness. This ambivalence can even be found in the second period, after the War of Liberation. There is a ycarning for the friendship and brotherhood of days gone by, set against the depressing reality of their own time. The motive of love and hatred appears frequently in the literature of this period. The three main motives of the Arab way of life that are described are vengeance, sexual lust and treachery.

In the second period, after the War of Liberation of 1948, several approaches to the Arabs appear in the lsraeli Hebrew literature. A naive approach can be discerned in works written for the youth. The literature for the youth consists of two main types, namely legends, folktales, travel and adventure stories with a didactic purpose on the one hand and stories in which the author reminisces about bygone days on the other hand. In these stories the Arab problem is touched on in a naive and simplistic manner. The brot herhood between Jews and Arabs is often emphasized, linked to the idea of pcaceful co-existence. This is especially true of the stories about the early shepherds and pioneers. This can be seen from the repetition of one of the ideas of the carly writers in a work of Agmon of 1960 , namely that the fellahin are not other than the Hebrews left behind in the land after the exile. Romanticism is indeed one of the important elements of these stories. A clear distinction is often made between the Arabs as a group - chiefly a hostile group - and the individual Arab - being often quite friendly and peaceful. For didactic purposes the human relationships of mutual responsibility, neighbourliness and peace are often emphasized.

The stories in which the authors reminisce about the time of their youth constitute an important landmark in Israeli literature in the transition to a problematical approach to the Arabs. The authors of these stories were sabras from the generation of the Palmach. They knew the Arabs as an inseparable part of the way of life of their childhood. A yearning after the world of childish simplicity can often be found in their stories. That world disappeared duc to the new tensions. That world that will be no more, with 
its peace and brotherhood, is remembered with nostalgia. The complications of the situation after the War of Liberation are forgotten in the memories of the time that was.

Another section of the writers of the generation of the Palmach faced the problems of their own times squarely. They commenced writing in the years of the Second World War and immediately afterwards and were almost exlusively graduates of the pioneer youth movement. Many of them had ties with Kibbutzim. Their world view was socialistic, stressing the ideals of the equality of man, the brotherhood of nations and the importance of the class struggle. These values started to disintegrate due to Israel's confrontation with the Arabs. Their starting-point was their own war experiences. The Arabs were part of their childhood experiences, but they became enemies in war. This resulted in confusion in their souls, confusion that is often expressed in their writings.

The political problems that started with the awakening of $A$ rab nationalism before the Second World War increased the hostility between Jews and Arabs. This increase in hostility plays the central role in many stories. The enmity of the Arabs is even ascribed to envy on the part of the Arabs of the agricultural and other successes of the Jews. Before the War of Liberation there were some binding factors, such as the common struggle against the British authorities, but after the war the alienation increased rapidly.

This caused complex feelings of guilt in the minds of some of these writers, remorse, conflicting emotions and even self-flagellation. This remorse was caused by the actions the Jews had to take against the Arabs. Yizhar for example saw the moral problems quite clearly, matters of conscience playing an important role in his writings. He pointed out the experiences of the Jews during the Holocaust and demonstrated that the Jews did comparable things to the Arabs after the War of Liberation. In his story Hirbet Hizca (1949) he illustrates the rough handling of the Arabs by the Jewish soldiers. He touches on the moral problem in this manner and has an eye for that which is wrong in one's own midst. The didactic aims of this description are quite clear. This story stirred up quite a controversy, the public secing in the very fact of the expulsion of the Arabs a failure inherent in the Israeli victory ${ }^{3}$. Alt hough the expulsion can be militarily justified, it amounts to the repression of one nation by another that has experienced

${ }^{3}$ Mr Friedman's study is available from the library of the University of Potchefstroom, Republic of South Africa. 'The references to the primary material on which Mr Friedman's views are based, can be found in his study. For the sake of brevity, references are omitted in this paper. 
repression in its own history. These moral problems also find expression in the works of other authors of this period, such as $\mathrm{J}$. bar Yosef. They were faced by a struggle bet ween two peoples for the right to one homeland. This tendency can also be discerned after the subsequent wars between Isracl and the Arab states.

The $\Lambda$ rab refugees are often referred to by these writers and their situation is compared to the experiences of the Jews through the ages. This whole matter of the Arab refugees became a central political problem in the Isracli-Arab conllict. The attention, even sympathetic attention as in the case of $A$ Meged, paid to this problem need thereforc not cause surprise.

Closer to the present time the ties of acquaintanceship which tied the Hebrew writer to the person of the Arabs and to their way of life gradually loosened. These ties can still be seen in the work of Yizhar, but since his time it has gradually faded. The focus is directed to the Arabs who remained in the land with thcir demands for education, their desire to flee or to change the situation by way of social progress. The old Arab way of life is no more. The social changes are described. This caused a struggle in the minds and life of the Arals. This struggle between the world of a previous era and the new situation is often quite sympathetically described. The political and security implications of the $A$ rab problem also receives due attention in the literature. 'The ideal to displace hostility with friendship by way of personal contact between Arabs and Jews is frequently expressed. This ideal is often thwarted by mutual reticence, as can be seen in stories dealing with love between members of the two peoples.

Since the beginning of the 1960's a new generation of writers have appeared on the scene, the Young Guard, also called the Generation of the State. Important figures amongst them are $Y$. Retush and $A$. Amir. In their works a spiritual severance from the Jewish cultural heritage of the Diaspora and a return to the ancient Canaanite mythology, to the sources of the Canaanite Hebrew culture of the biblical period can be discerned. The people of the settlements are for them the Canaanites or the Hebrews. They saw their work as an organic continuation of the Bible and its ancient CanaaniteSemitic literature. There are also many themes of the writers of the first period that recur in the work of the so-called Canaanites, especially the romantic chalutzic idcals of the Second Aliyah.

The fateful meeting betwcen the two peoples and the struggle for their birthright in the homeland are expressed in terms of a decisive life and death confrontation. There is a political and militaristic trend in their approach against the romantic and legendary solution to the correspondingproblems 
of the first period. The Arabs are for them an existential condition and an historical destiny with which one had to struggle, and overcome by force. The fight against terrorism plays an important role in their work. Some of these writers even display a tendency to chauvinism, Shamir e.g., furthering hatred and alienation by a one-sided approach to the problem.

These feelings of hatred and alienation did make their first appearance in the first period, especially in the writings of Brenner. In his time the Jews were a minority amongst the Arabs in Palestine. This is paralleled in modern times by the state of Israel being encircled and dissected by hostile Arab states and an insecure and artificual border. The Arab problem has implications for the daily existence of the Jews in Israel. The tragic side of the conflict does not escape notice. Yizhar saw the moral problem but for $\mathrm{Oz}$ the $\Lambda$ rabs are an existential condition. The Arabs are a daily threat, with the result that $\mathrm{Oz}$ even regards the landscape as part of the menace of the enemy, that lives in and infiltrates the landscape.

Although these writers like to see their work as a continuation of the literature of the biblical period they cannot totally ignore the Holocaust, the fate of the Arabs being seen as a reflection of the historic fate of the Jews. Remorse also plays a part in their work, the state of Israel having been built on Arab ruins.

It is quite clear that the changing milieu of the Israeli writers since the beginning of this century till the present day has had an important - almost decisive - influence on their views on and portrayal of the Arabs. In his defining of the different trends in the different periods Benjamin Friedman made an important contribution to the understanding of the portrayal of the Arabs in Israeli fiction.

This story also features prominently in Rotshtein's paper; cf. e.g. pp. 485, 6 and 9. 